\title{
O ESSENCIAL E O ACIDENTAL: BODIN (E HOBBES) E A INVENÇÃO DO CONCEITO MODERNO DE CONSTITUIÇÃO*
}

\author{
Bernardo Ferreira
}

Depois do que dissemos sobre a soberania e sobre seus direitos e suas marcas, é preciso ver quem são aqueles que em toda república detêm a soberania, para avaliar qual é o estado [estat]. Quando a soberania reside em um só príncipe, nós o designaremos de monarquia; se o povo tem parte nela, nós falaremos que o estado é popular; no caso de somente uma parte do povo, podemos avaliar que o estado é aristocrático. E usaremos essas palavras para evitar a confusão e a obscuridade que advêm da variedade dos governantes bons $e$ maus, os quais deram ocasião para que muitos apresentassem mais de três tipos de república. Mas, se essa opinião tem lugar e o estado das repúblicas é apreciado com base nos vícios e nas virtudes, haverá um mundo deles. Ora, é certo que, para
\end{abstract}

\footnotetext{
* Este trabalho é fruto da pesquisa "Em busca do processo constituinte: 19851988", financiada pelo CNPq (Edital Universal 15/2007), e também se beneficiou de apoio da Faperj. Agradeço a Jaime Fernando Villas da Rocha pelas sugestões e conversas em torno dos temas deste artigo.
} 
que tenhamos definições verdadeiras e resoluções em todas as coisas, não basta que nos detenhamos nos acidentes, que são inumeráveis, mas, antes, nas diferenças essenciais e formais.

De outro modo, poderemos cair em um labirinto infinito, em que não cabe ciência. [...] Uma vez que a qualidade não altera a natureza das coisas, nós diremos que só existem três estados, ou três tipos de república, a saber a monarquia, a aristocracia e a democracia (Bodin, 1583, pp. 251-2) .

O trecho anterior pertence ao capítulo de abertura do Livro II de Les six livres de la République ( $1^{\mathrm{a}}$ edição de 1576), de Jean Bodin, intitulado "Des toutes sortes de Républiques en general et s'il en a plus de trois" [Sobre todos os tipos de república em geral e se há mais do que três]. Um leitor minimamente familiarizado com a história do pensamento político ocidental não terá dificuldade de identificar aqui a reiteração de um dos mais constantes e repetidos topoi her382 dados da tradição clássica: a distinção entre as formas "constitucionais" de acordo com o número dos governantes ${ }^{2}$. Bodin, porém, ao retomar a diferenciação entre monarquia, aristocracia e democracia, recusa um critério que também fora legado e consagrado pela tradição clássica. Para ele, a distinção entre "constituições" justas e injustas, retas e desviadas, ou seja, a diferenciação segundo o modo como são exercidas as funções públicas, não é relevante. Esse critério, afirma o jurista, introduz uma modulação qualitativa

\footnotetext{
${ }^{1}$ Cito a partir da edição de 1583, que, na ausência de uma edição crítica do livro, é, segundo Julian Franklin (1992, pp. xxxv-xxxvi), a edição mais comumente utilizada pelos especialistas em Bodin, tendo servido de base às traduções italiana $\mathrm{e}$ alemã do livro. Traduzo a palavra francesa "estat" por "estado", com letra minúscula, pois no texto de Bodin a noção que designa algo próximo ao nosso conceito de Estado seria République. Como observa Simone Goyard-Fabre (1989, p. 140), o termo estat remete à noção latina de status, a qual não designa a unidade política, mas a sua condição, como ocorre, por exemplo, na expressão status rei publicae (Ver Senellart, 2006, p. 24).

${ }^{2}$ Sobre a classificação das constituições entre os gregos, pode-se consultar Romilly (1959).
} 
na análise, que desvia a atenção dos aspectos essenciais para os acidentais e, no fim das contas, multiplica indefinidamente as possibilidades de classificação.

Bodin reintroduzirá essa distinção qualitativa por intermédio da diferenciação entre estat ("estado") e gouvernement ("governo"), apresentada no capítulo 2 do Livro II. O primeiro termo, como a citação anterior deixa entrever, remete às diferentes formas que a república pode assumir, a depender do número daqueles que são os portadores da soberania. Já a noção de "governo" é menos precisa ${ }^{3}$. Bodin emprega a palavra, por um lado, para designar os agentes responsáveis pela execução da vontade do soberano. Nesse caso, existiriam três tipos distintos de governo: popular, caso todos os súditos participem do governo; aristocrático, se apenas uma parcela privilegiada participa; e harmônico, quando se dá uma combinação das duas formas anteriores. Ao mesmo tempo, a noção de governo pode assumir uma feição mais francamente qualitativa e se referir ao modo de exercício da soberania, resultando em três modelos: real ou legítimo, senhorial ou despótico e tirânico. No primeiro caso, os súditos obedecem às leis do soberano e esse último exerce o poder em conformidade com os ditames da lei natural; no segundo, a república é governada à semelhança do governo da casa e o soberano age em relação ao seu reino e seus súditos como o pai de família dispõe dos bens pessoais; no terceiro, o soberano despreza as leis da natureza e de Deus e abusa de seu poder, reduzindo súditos livres à condição de escravos (Bodin, 1583, p. 273).

A distinção entre "estado" e "governo" tem um alvo polêmico e permite a Bodin extrair importantes consequências teóricas e políticas a respeito dos limites do poder soberano. Mais especificamente, ela está a serviço de uma controvérsia em que o autor de Os seis livros da república se

\footnotetext{
${ }^{3}$ Acompanho aqui as observações de Barros (2001, pp. 299-331). Para uma abordagem da distinção entre estado e governo em Bodin, tendo em vista o contraste com os teóricos da "razão de Estado", ver Foisneau (2009).
} 
opõe ao constitucionalismo protestante, surgido na sequência do episódio da Noite de São Bartolomeu, em 1572, e à ideia de "constituição mista" . A exploração mais detida dessas questões exigiria encaminhar minha análise numa direção que escapa aos objetivos do presente trabalho. Ainda assim, talvez valha a pena assinalar, de forma breve e inevitavelmente muito simplificada, um ponto que, acredito, permite ilustrar algumas das consequências políticas da recusa de Bodin em abordar as formas de república a partir de uma perspectiva qualitativa. Refiro-me, mais especificamente, a sua discussão sobre a tirania e a resistência ao tirano. A esse respeito, gostaria de fazer duas rápidas observações. Em primeiro lugar, graças à separação entre "estado" e "governo", Bodin pode considerar a tirania como um modo de exercício da soberania observável em todos os tipos de república, sejam estas monárquicas, aristocráticas ou democráticas $^{5}$. Dessa forma, a tirania não precisa ser considerada, 384 como queria a tradição, uma forma degenerada da monarquia. Como assinala Mario Turchetti (2001, p. 454), essa perspectiva é "nova sob diversos aspectos". Isso lhe permite, e esse é meu segundo ponto, preservar, simultaneamente, a noção da tirania como um modo injusto e desvirtuado de exercício de uma função pública e rejeitar como ilegítima a resistência aberta dos súditos ao governo tirânico ${ }^{6}$. Isso

\footnotetext{
${ }^{4}$ Para a análise da crítica de Bodin ao tema da "constituição mista" e seu confronto com o constitucionalismo protestante que se desenvolve a partir da Noite de São Bartolomeu, pode-se consultar: Franklin (1969, 1973); Spitz (1998); Skinner (2006); Barros (2006); Mesnard (1951).

${ }^{5}$ Como observa Bodin (1583, p. 273), "a mesma diferença se encontra no estado aristocrático e popular: porque tanto um como o outro podem ser legítimos, senhoriais ou tirânicos da maneira como disse. E a palavra tirania se usa também em relação ao estado turbulento de um povo furioso, como disse muito bem Cícero". ${ }^{6}$ Para efeito de simplificação da exposição, não estou levando em conta a diferença que Bodin estabelece entre a tirania resultante do abuso de poder e a tirania devida à usurpação de poder. Essa diferença retoma a distinção do jurista medieval Bartolo de Sassoferrato entre a tirania por exercício e a tirania por deficiência de título. Somente em relação ao primeiro caso, a tirania por abuso de poder, Bodin rejeita a resistência dos súditos.
} 
porque, com a separação entre "estado" e "governo", Bodin dissocia, pelo menos em parte, os títulos jurídicos de legitimidade de que o soberano está investido - ou seja, o seu direito exclusivo e perpétuo de dar a lei e de revogá-la do exercício efetivo de seu poder. Sendo assim, ao discutir o direito de resistência em relação a um monarca tirânico (Livro II, cap. 5), Bodin afirma que:

Se o príncipe é absolutamente soberano como são os verdadeiros monarcas da França, da Espanha, da Inglaterra, da Escócia, da Etiópia, da Turquia, da Pérsia, da Moscóvia, cujo poder não é colocado em dúvida, nem a soberania repartida com os súditos, nesse caso não cabe a um súdito em particular, nem a todos em geral atentar contra a honra, nem contra a vida do monarca, seja pela via de fato, ou pela via da justiça, ainda que ele tenha cometido todas as maldades, impiedades e crueldades que se possa conceber. Porque, no que se refere à via da justiça, o súdito não possui jurisdição sobre seu príncipe, do qual depende todo poder e autoridade de comando e o qual pode não apenas revogar todo o poder de seus magistrados mas também na presença de quem cessa todo poder e jurisdição de todos os magistrados corpos e colégios, estados e comunidades. [...] E se não é lícito ao súdito julgar seu príncipe, ao vassalo seu senhor, ao servo seu mestre, em resumo, se não é lícito proceder contra seu rei pela via da justiça, como ele poderia proceder pela via de fato? Porque não está em questão saber quem é o mais forte, mas apenas se é lícito em direito e se o súdito tem o poder de condenar seu príncipe soberano (Bodin, 1583, pp. 302-3).

Seria equivocado imaginar que a separação realizada por Bodin entre as "maldades, impiedades e crueldades" cometidas no exercício do poder soberano e o que é "lícito em direito" em relação à soberania implica redução do 
direito à norma legislada. Como observei há pouco, a dissociação entre os títulos jurídicos de legitimidade do soberano e o exercício efetivo do seu poder é parcial. Ignorar esse ponto implica desconsiderar o papel que, no pensamento do jurista francês, as leis de Deus e da natureza desempenham como limites normativos ao exercício da soberania. Como observa Bodin, "é uma incongruência em direito dizer que o príncipe pode coisa que não seja honesta, visto que seu poder deve sempre ser medido de acordo com justiça” (Bodin, 1583, p. 156) ${ }^{7}$.

Para o jurista, como se sabe, a superioridade do soberano em relação à lei se exerce no campo da lei civil, jamais em relação às leis da natureza, de Deus ou do reino. As leis da natureza, em particular, constituem princípios de equidade natural, normas invioláveis, às quais o príncipe se encontra obrigado em sua atividade legislativa. Ainda que essa obrigação não se traduza em controles "constitucionais" fortes 386 e claramente institucionalizados, ela não se reduz, como observa Jean-Fabien Spitz (1998, pp. 19-20), a um imperativo “'simplesmente moral' em qualquer sentido coerente do termo, uma vez que se trata de uma obrigação em face de uma norma que não é pensada como exterior às coisas, mas como inscrita no universo ordenado". Não por acaso, é a própria noção de lei natural que está na base da definição de tirania proposta por Bodin (Livro II, cap. 4): o tirano é, em primeiro lugar, um violador da lei da natureza. Por essa razão, embora afirme ser ilícita a resistência aberta dos

\footnotetext{
${ }^{7}$ Nesse sentido, o trabalho anteriormente citado de Jean-Fabien Spitz (1998, p. 18) busca oferecer um contraponto a uma visão da obra de Bodin que tende a acentuar o seu papel de inaugurador de uma concepção moderna do direito, na qual a importância da lei natural é esvaziada em benefício do direito legislado. Como observa o autor, "se o príncipe é legislador, ele só pode exercer essa função de posição de normas comuns para a manutenção e a salvaguarda de normas anteriores a toda posição humana, o que tem como efeito submeter a própria atividade legislativa a uma normatividade não positiva que a precede e que invalida os desdobramentos contrários a esse direito obrigatório anterior".
} 
súditos a uma monarquia tirânica e recuse categoricamente o tiranicídio contra um monarca que não seja um mero usurpador, Bodin considera não só legítimo, como também louvável, que um príncipe estrangeiro se volte, inclusive pela via das armas, contra um governante desse gênero ${ }^{8}$.

Não obstante, ao distinguir entre essencial e acidental, Bodin coloca em segundo plano, do ponto de vista dos critérios de classificação das formas de república, a superioridade hierárquica dos princípios objetivos de justiça encarnados na lei da natureza. Isso o conduz a uma definição das formas de república que, simultaneamente, se nutre das referências do pensamento "constitucional" da tradição clássica e medieval e, ao mesmo tempo, se afasta delas. Chamo a atenção para esse ponto, pois gostaria de sustentar uma tese: a de que essa separação entre o essencial e o acidental, proposta por Bodin, representa um passo decisivo na construção do moderno conceito de constituição. Essa afirmação não é evidente e, diria mesmo, tem algo de contraintuitivo. E isso por algumas razões. Em primeiro lugar, pelo dado cronológico: há certo consenso a respeito de que a noção moderna de constituição date do século XVIII e se consolide em definitivo com as Revoluções Americana e Francesa. Em segundo lugar, uma das características das constituições modernas está na tentativa de regulação e controle do exercício do poder político pelo estabelecimento de um conjunto de normas positivas tidas como fundamentais e superiores em relação às demais normas resultantes da atividade legislativa ordinária (Grimm, 2006, pp. 46, 49, 50; Stourzh, 2007, p. 98).

\footnotetext{
8 "Há muita diferença entre dizer que o tirano pode ser licitamente morto por um príncipe estrangeiro ou por um súdito. Assim como é muito belo e apropriado que alguém, quem quer que seja, defenda pela via de fato os bens, a honra e a vida daqueles que se encontram injustamente oprimidos, quando a porta da justiça está fechada, [...] da mesma forma é algo muito belo e magnífico que um príncipe tome em armas para vingar um povo injustamente oprimido pela crueldade de um tirano" (Bodin, 1583, p. 300).
} 
Ora, Bodin, como se sabe, concebe a soberania em termos absolutos, ou seja, como uma capacidade exclusiva e indivisível de dar e de revogar a lei civil. O soberano, nesse sentido específico, é legibus solutus, não está submetido à lei que ele mesmo estabeleceu e tampouco a qualquer outra autoridade pública, pois, se assim fosse, estaria sujeito à capacidade legislativa de outrem. Portanto, ao definir os tipos de república em termos da noção de soberania, Bodin recusa a possibilidade de controles "constitucionais" positivos sobre o soberano no exercício de sua capacidade legislativa. Essa é uma das razões pelas quais Bodin, a partir da distinção entre o essencial e o acidental, rejeita categoricamente uma forma mista de "estado", embora, ao mesmo tempo, admita uma forma mista de "governo". A combinação de formas distintas na atividade "governamental" não afeta as prerrogativas legislativas do soberano, apenas o exercício das funções administrativas. Quando reconhe388 ce limites jurídicos positivos, e esse é meu terceiro ponto, Bodin o faz com referência às "leis concernentes ao estado do reino" (Bodin, 1583, p. 137). Essa noção remete à ideia das leges fundamentales [leis fundamentais], característica do pensamento "constitucional" anterior ao final do século XVIII, embora Bodin não chegue a usar a expressão "lei fundamental” (Grimm; Mohnhaupt, 2008, p. 57). Voltarei mais adiante à noção de lex fundamentalis. Por ora basta indicar que as premissas intelectuais desse conceito são inteiramente distintas da ideia moderna de constituição como "lei fundamental", que se consagra em fins do século XVIII.

Essas objeções, como afirmei anteriormente, têm algo de intuitivo, uma vez que elaboram uma percepção mais ou menos imediata de que a reflexão jurídico-política de Bodin é, em linhas gerais, estranha à ideia moderna de constituição. Seria ingênuo, acredito, ignorar essa percepção. Basta levar em conta o papel que, a partir da Revolução Americana, a noção de direitos individuais fundamentais 
teve na definição das constituições modernas para dimensionar o quão distante Bodin se encontra em relação a estas últimas ${ }^{9}$. Por outro lado, parece-me que, embora corretas, essas objeções apreendem apenas um aspecto do problema. Sendo assim, para sustentar meu ponto recorrerei à história do conceito de constituição, com o objetivo de pôr em evidência algumas das premissas intelectuais que, a meu ver, seriam definidoras do moderno conceito de constituição. Gostaria de fazê-lo explorando os contrastes entre este conceito e noções cronologicamente anteriores que lhe são próximas. Em primeiro lugar, recuperarei elementos da história da ideia moderna de constituição, com ênfase na distinção entre a noção tradicional de lex fundamentalis e a constituição como uma "lei fundamental". Em seguida, retomarei alguns aspectos da formação histórica do conceito grego de politeia, visando assinalar o vínculo entre a constituição moderna e certa compreensão da natureza da unidade política que vem a ser por ela ordenada.

Antes de prosseguir, porém, creio ser necessário fazer uma breve distinção relativa ao modo como a palavra constituição e o adjetivo correspondente serão utilizados ao longo do texto. Por um lado, constituição será empregada como categoria heurística. Nesse caso, o termo pretende ter um alcance geral, desvinculado de uma situação histórica específica e se refere ao problema da ordem no âmbito da "cidade" e suas implicações quanto à organização das funções públicas e às condições de seu exercício. Por outro, a palavra se referirá a um conceito particular, surgido nas sociedades ocidentais a partir, sobretudo, do século XVIII. Nesse caso, o termo constituição se apresenta como uma categoria histórica que, para empregar o vocabulário do historicismo, se define por sua individualidade e, em última

\footnotetext{
${ }^{9}$ Sobre a importância da noção de direitos individuais fundamentais na definição das constituições modernas, podem ser consultados os trabalhos de Gerald Stourzh $(1977,1979,1988,2007)$.
} 
análise, por sua incomensurabilidade em relação a outros conceitos "equivalentes" como politeia e lex fundamentalis.

\section{II}

A consolidação da ideia de constituição moderna no final do século XVIII na América e na França implicou a passagem de uma noção de características descritivas para um conceito prescritivo. Dieter Grimm (2006, pp. 27-8) sintetiza as linhas gerais desse desenvolvimento nos seguintes termos:

O termo constituição [...] foi inicialmente um conceito empírico, que passou do âmbito da descrição da natureza ao da linguagem jurídico-política para designar a situação de um país, a forma pela qual este se configurou mediante as características de seu território e seus habitantes, sua evolução histórica e as relações de poder nele existentes, suas normas jurídicas e instituições políticas. No entanto, com o esforço de limitar o poder do Estado em benefício da liberdade dos súditos, que penetrou desde meados do século XVIII na doutrina do direito natural, o conceito de constituição se estreitou progressivamente, eliminando gradualmente os elementos não normativos, até que a constituição apareceu unicamente como a situação determinada pelo direito público. Somente com as revoluções de fins do século XVIII na América do Norte e na França, que aboliram pela força a soberania hereditária e erigiram uma nova sobre a base da planificação racional e a determinação escrita do direito, se consumou a transição de um conceito do ser a um do dever-ser. ${ }^{10}$

O sentido mais preciso dessa passagem do plano do ser ao do dever-ser torna-se mais claro se considerarmos alguns aspectos do desenvolvimento histórico do conceito.

\footnotetext{
${ }^{10}$ Para a caracterização dessa passagem, ver também Grimm (2006, pp. 49-50, 107-108).
} 
Nos séculos XVI e XVII, a palavra constituição-ao contrário do que se poderia esperar, considerando-se a posição que, hoje, ela ocupa no nosso vocabulário político-jurídico - não era empregada como equivalente ao termo grego politeia ${ }^{11}$. Nas línguas inglesa e francesa, outros vocábulos eram utilizados para verter a palavra grega: res publica, commomwealth, policy, polity, government, république, police, gouvernement. A palavra constituição era estranha ao vocabulário político, ao que tudo indica, até pelo menos a passagem do século XVI para o XVII. Uma consulta a dicionários franceses dos séculos XVII, e mesmo do XVIII, revela os significados predominantemente vinculados à palavra ${ }^{12}$. Em primeiro lugar, constituição se refere à condição, estado, composição de alguma coisa, como a "constituição de um corpo", a "constituição do céu". Esse sentido da palavra aparece frequentemente associado à medicina e, portanto, à qualidade e condição de um corpo humano, ou seja, a sua "constituição física”. Outra acepção do termo possui conotação mais especificamente jurídica, oriunda do vocabulário do direito romano, no qual constitutio era uma designação para decretos imperiais. No direito canônico, a palavra, normalmente empregada no plural, adquire o sentido de normas, regulamentos eclesiásticos escritos, à diferença de convenções ou do costume. Algo de semelhante se observa no âmbito do direito inglês, em que o termo constitutions referia-se a regulamentos de nível inferior e, normalmente, de caráter local (Stourzh, 2007, p. 93).

A incorporação do termo constituição ao vocabulário público se deu por intermédio de progressiva extensão

\footnotetext{
${ }^{11} \mathrm{O}$ termo politeia, ao qual retornarei mais adiante, é frequentemente traduzido nas línguas contemporâneas por constituição ou regime. Para o que se segue, minhas principais referências serão os seguintes textos: Stourzh $(1988,2007)$; Beaud (2009); Grimm; Mohnhaupt (2008); Grimm (2006). Também consultei Böckenförde (1999), Fioravanti (1999) e MacIlwain (1991).

${ }^{12}$ Para essa referência específica aos dicionários, ver Valensise (1987) e Grimm; Mohnhaupt (2008).
} 
desses significados para o domínio da política. Em primeiro lugar, pela analogia, não raro com conotações médicas e biológicas, entre os corpos físicos e os corpos políticos. Dessa forma, ao longo do século XVII, no âmbito da língua inglesa tornou-se possível falar da constitution of the commonwealth, constitution of the kingdom, constitution of government ${ }^{13}$. Por se referir à condição de um objeto específico, a palavra constituição não é normalmente empregada de forma isolada, ela requer a indicação de um referente e, não raro, de um complemento qualificativo. Fala-se, portanto, da "boa/antiga/natural constituição da república/ do reino/do governo". A história do termo, sobretudo no século XVIII, corresponde, como observa Olivier Beaud (2009, p. 9), a uma "autonomização de seu significado político”. O uso reiterado da palavra constituição para descrever a qualidade de determinado corpo político permitiu, com o tempo, prescindir da analogia explicativa com os corpos 392 naturais. Com isso, estabelece-se uma aproximação entre a ideia de constituição e certa ordem da vida estatal e das relações políticas, de modo que a palavra, no fim das contas, pôde ser empregada isoladamente, sem a referência ao objeto (o reino, a república, o governo), cuja condição lhe caberia descrever. $\mathrm{O}$ termo constituição, portanto, tenderá a se desvincular da associação, de cunho descritivo, com a qualidade de um objeto determinado, passando a designar um objeto em si mesmo, ou seja, certa disposição e organização das instituições públicas.

Por essa via, constituição veio a adquirir o status de um conceito político e pôde ser utilizada para se referir ao modo como se ordenam as funções públicas no interior da cidade, ou seja, àquilo que nos termos da tradição do pensamento político aristotélico corresponderia a uma politeia. No século XVIII, esse uso eminentemente político da

\footnotetext{
${ }^{13}$ Para exemplos, ver Stourzh $(1988,2007)$.
} 
palavra constituição se difunde em primeiro lugar na Inglaterra $^{14}$. No continente, Montesquieu desempenhará um importante papel na fixação conceitual desse significado político, ao usar constituição com um sentido próximo ao de politeia $^{15}$. Esse também é, em linhas gerais, o sentido da importante definição de constituição proposta pelo jurista suíço Emer de Vattel em um livro amplamente difundido na segunda metade do século XVIII, Le Droit de Gens, de 1758, em que se pode ler nos parágrafos 27 e 28 do Livro I:

\section{[...] a regulação fundamental que determina a maneira} pela qual a autoridade pública deverá ser exercida é o que forma a constituição do Estado. Nela se vê a forma sob a qual a nação age na qualidade de corpo político, como e por quem o povo deve ser governado, quais são os deveres e o direito daqueles que governam. Essa constituição, no fundo, não é outra coisa que o estabelecimento da ordem na qual uma nação se propõe a trabalhar em comum para obter as vantagens em vista das quais a sociedade política se estabeleceu. [...] É, portanto, a constituição do Estado quem determina sua perfeição, sua aptidão para preencher os fins da sociedade e, por conseguinte, o maior interesse de uma nação que forma uma sociedade política, seu mais importante e primeiro dever em relação a si mesma é escolher a melhor constituição possível e a mais adequada às circunstâncias.

\footnotetext{
${ }^{14}$ Veja-se, por exemplo, a definição de constituição que Bolingbroke oferece do termo em 1733: "por constituição entendemos, sempre que falamos com propriedade e exatidão, essa reunião de leis, instituições e costumes, derivada de certos princípios fixos da razão, dirigida a certos objetos do bem público, que compõe o sistema geral, de acordo com o qual a comunidade aceitou ser governada" (apud Stourzh, 2007, p. 92).

${ }^{15}$ Essa é a posição de Olivier Beaud (2009, p. 11), segundo a qual "Montesquieu elevou a palavra constituição à dignidade do conceito, e o fez ao fazê-la endossar um sentido que, então, era próximo da antiga politeia".
} 
Ainda segundo Vattel,

[...] as leis que são feitas diretamente em vista do bem público são as leis políticas; e, nessa classe, aquelas que dizem respeito ao corpo mesmo e à essência da sociedade, à forma do governo, à maneira como a autoridade pública deve ser exercida; aquelas, em uma palavra, cujo concurso forma a constituição do Estado, são as leis fundamentais.

(Vattel, 1758, pp. 31-2)

Duas rápidas observações a respeito das definições propostas por Vattel. Embora referida à noção tradicional de corpo, não creio ser difícil reconhecer que esta definição não se esgota na simples descrição de um certo estado de coisas. A autonomização do sentido político de constituição, sua aproximação com a ideia clássica de politeia permitem introduzir na palavra um ingrediente normativo. Vattel não 394 se refere apenas à composição e à ordem concretas dos Estados particulares. Ele também concebe a constituição diga-se de passagem, em inteira sintonia com a tradição clássica - como a melhor ordem a ser instituída. Com isso, o conceito adquire dupla valência, que permite a passagem do plano empírico para o prescritivo. Em segundo lugar, ao conceber a constitution de l'Etat como um conjunto de leis fundamentais, Vattel remete sua definição a um conceito herdado dos debates político-jurídicos do Antigo Regime a respeito dos limites da autoridade pública. Dessa forma, o autor suíço associa, ao termo constituição, um componente jurídico que é estranho à noção clássica de politeia. Este componente, como veremos, será central na formação da ideia moderna de constituição como lei fundamental, surgida no final do século XVIII. No entanto, apesar desse vínculo entre constituição e leis fundamentais, seria equivocado procurar em Vattel uma espécie de antecipação do conceito consagrado na época revolucionária. Como observa 
Heinz Mohnhaupt (1988, p. 156), a ideia de constitution de l'Etat proposta pelo jurista não se apresenta como "um texto constitucional independente, fechado em si, mas ainda está conceitualmente ligada a uma pluralidade de leis fundamentais individuais designadas em termos de conteúdo e as reúne em si numa unidade significativa" ${ }^{16}$. Vejamos com mais atenção esse ponto.

A noção de lex fundamentalis - ou, para ser mais exato, leges fundamentales, pois o termo era normalmente empregado no plural - se forma no interior das controvérsias políticas e religiosas da França da segunda metade século $\mathrm{XVI}^{17}$. O termo se refere a um conjunto de normas invioláveis e vinculantes, que constituiriam o fundamento da ordem pública. Nesse sentido, as leis fundamentais pressupõem uma diferenciação, no interior do próprio direito, entre dois tipos de normas particulares de caráter positivo: aquelas que se apresentam como fundamento da ordem pública, sendo, por isso, permanentes e inalteráveis, e aquelas passíveis de modificação, por estarem submetidas ao arbítrio do governante. No caso da monarquia francesa, um exemplo característico da ideia de lei fundamental, invocado tanto por partidários da monarquia absoluta como pelos defensores da sua limitação, é a "lei sálica", que estipularia a obrigatoriedade da descendência masculina do trono real.

\footnotetext{
${ }^{16}$ Outro aspecto muito importante a ser destacado na definição de Vattel é o papel que ele atribui à ideia de nação. Para Vattel, é a nação que estabelece sua própria constituição e é exclusivamente ela quem tem o direito de alterá-la. As instâncias legislativas ordinárias não possuem essa prerrogativa, pois devem sua existência à própria constituição. O tema da nação e, em particular, da nação constituinte que, creio ser possível dizer, se anuncia na reflexão de Vattel - ocupará um lugar decisivo na elaboração do moderno conceito de constituição, sobretudo a partir dos debates políticos da França revolucionária. Não pretendo ignorar esse aspecto do conceito, no entanto, tendo em vista a discussão que desenvolvo neste texto, não me ocuparei dele de maneira mais detida.

${ }^{17}$ Sigo aqui as indicações de Mohnhaupt (1988); Grimm; Mohnhaupt (2008). Também utilizei Seelaender (2006).
} 
O conteúdo da noção de leis fundamentais não é fixo, variando de um lugar para outro, e, desse modo, seu caráter é sempre particular e concreto, ainda que seja possível identificar alguns temas recorrentes: a inalienabilidade do patrimônio público, a obrigatoriedade do respeito aos vínculos contratuais entre o governante e os estamentos, a preservação da forma de governo etc. A despeito da recorrência de alguns conteúdos, importa enfatizar a natureza eminentemente concreta da noção de leges fundamentales: as leis fundamentais de um Estado dizem respeito àquele Estado específico, mesmo que uma formulação equivalente possa ser encontrada em outro lugar. Por outro lado, embora as leges fundamentales refiram-se a normas inalteráveis que impõem limites à autoridade pública, isso não significa que elas tenham sido sempre usadas politicamente no sentido de uma limitação "constitucionalista" do poder. A partir das décadas finais do século XVI, tanto os partidá396 rios da causa absolutista, quanto os defensores de um regime limitado recorrerão ao conceito (Beaud, 2003, p. 135; 2009, pp. 14-7).

O conceito de "leis fundamentais" tem, portanto, um sentido jurídico que a palavra constituição, num primeiro momento, desconhecia. A aproximação entre os dois termos permitiu, por conseguinte, trazer a ideia de constituição para o âmbito do direito, atribuindo-lhe um alcance jurídico-normativo. Ou seja, a constituição, como vimos a propósito da definição de Vattel, pôde ser encarada como um conjunto de normas jurídicas que compõe o fundamento da vida do Estado. Um dos caminhos que conduziu a essa direção foi retraçado por Gerald Stourzh, no âmbito de língua inglesa, a partir do uso no debate político do século XVII da expressão fundamental constitutions. Segundo o autor, o surgimento da expressão foi o resultado do resgate da palavra constitution, derivada do termo jurídico latino constitutio. A palavra é retomada no debate políti- 
co do século XVII em associação com a ideia de fundamental laws, adquirindo, com isso, um novo valor. No entanto, o passo decisivo do ponto de vista da formação do moderno conceito de constituição como "lei fundamental" não se encontra ainda nessa nova construção verbal, nem tampouco, já assinalei esse ponto, na identificação estabelecida por Vattel entre constituição e um conjunto de leis fundamentais. É preciso dirigir a atenção para a interpretação particular que, no mundo anglo-saxão, foi dada para a ideia de lei fundamental e para seus desdobramentos nos debates jurídico-políticos do período da independência norte-americana.

$\mathrm{Na}$ Europa continental, como vimos, a noção de leis fundamentais remetia a normas objetivas relacionadas à ordem do Estado (regras de sucessão, inalienabilidade do patrimônio público etc.) ou a regras relativas aos laços contratuais entre o monarca e os estamentos e, portanto, aos direitos dos estamentos e corporações em face do soberano. Já na Inglaterra - e, por extensão, em suas colônias -, a mesma noção foi esvaziada, ao longo do século XVII, de seu conteúdo prioritariamente estamental e corporativo, passando a ter como principal referência um conjunto de direitos individuais dos ingleses ${ }^{18}$. Daí a possibilidade de se falar igualmente de fundamental laws, fundamental rights ou, apenas, fundamentals (Stourzh, 1979, p. 351).

Durante o processo de independência norte-americano, a imagem de que esses "direitos fundamentais" estavam sendo violados pelo arbítrio do Parlamento inglês e de que, logo, precisavam de proteção, desempenhou um papel decisivo na formulação da ideia de constituição moderna. Como observa Gerald Stourzh, para os americanos do final do século XVIII, a constituição veio a ser algo mais do que um modo de organização e distribuição das funções públi-

\footnotetext{
${ }^{18}$ Sobre essa especificidade do mundo inglês, ver Mohnhaupt (1988, pp. 150-1) e, sobretudo, Stourzh $(1977,1988,2007)$.
} 
cas no interior do Estado. Ou seja, algo mais do que os significados político-institucionais herdados da noção grega de politeia. Nesse sentido, a defesa de uma constituição durante a Revolução Americana não se esgotou na demanda por certa forma de organização da vida política, mas também trouxe consigo o problema da proteção dos direitos individuais. Essa questão se apresenta com toda a clareza numa afirmação contida nas resoluções do town meeting de Concord, de 1776:

\section{[...] nós entendemos que uma concepção apropriada} de constituição compreende um sistema de princípios estabelecido para garantir ao súdito a possessão e o desfrute de seus direitos e privilégios contra quaisquer abusos da parte do governo (apud Stourzh, 1988, p. 166).

Dessa forma, a partir da Revolução Americana, a cons398 tituição foi imaginada como um instrumento público de proteção dos direitos subjetivos dos cidadãos de um Estado. O resultado foi que, para desempenhar o papel de garantia de direitos fundamentais, a constituição veio a ser concebida como $a$ lei fundamental. Diferentemente, porém, da ideia tradicional de lex fundamentalis, que implicava a referência a um conjunto de normas particulares e concretas, essa natureza fundamental da constituição decorre de uma característica jurídico-formal. Tentando ser um pouco mais claro: o que torna uma constituição, compreendida nesses termos, uma lei fundamental é, antes de tudo, sua superioridade formal no interior de um sistema de normas jurídicas, ou seja, o fato de que ela se apresenta como uma lei suprema, anterior a todo governo constituído e capaz de invalidar qualquer ato legislativo que lhe seja hierarquicamente inferior. Ao serem acolhidos no interior de uma ordem jurídica desse gênero, isto é, ao serem constitucionalizados, os direitos fundamentais passam a estar revestidos por essa 
condição de superioridade formal, não podendo ser revogados por qualquer ato legislativo ordinário. No debate jurídico-político americano essa novidade foi sintetizada de modo exemplar pelo juiz John Marshall, na Suprema Corte norte-americana, em 1803:

[...] certamente todos aqueles que elaboraram constituições escritas consideram que elas formam a lei suprema e fundamental da nação e, por conseguinte, a teoria de todo governo desse tipo deve ser que um ato do legislativo contrário à constituição é nulo (apud Stourzh, 2007, p. 98) ${ }^{19}$.

É importante assinalar que a supremacia da constituição não resulta apenas da novidade de que, a partir de agora, ela se apresenta como um documento escrito no qual se estabelecem princípios centrais da vida pública. É verdade que a redação de um documento, ao firmar por escrito uma série de preceitos jurídicos, confere a estes preceitos uma espécie de objetividade. Porém, seu caráter de "lei fundamental" é, em primeiro lugar, fruto de sua separação formal em relação às leis ordinárias. Nesse sentido, como observa Olivier Beaud (2009, p. 24; 2003, p. 135), o conceito consagrado pela Revolução Americana implicou uma "juridicização da constituição". O sentido dessa observação torna-se mais claro quando se considera a diferença entre a ideia tradicional de lex fundamentalis e a nova imagem da constituição como a "lei fundamental". No primeiro caso, já assinalei esse ponto, o caráter fundamental das leges fundamentales decorre de que estas se apresentam como um conjunto de normas particulares e concretas, às quais se atribui uma validade objetiva e, por isso, um caráter obrigatório.

\footnotetext{
${ }^{19}$ A ideia de constitucionalização dos direitos fundamentais é desenvolvida por Gerald Stourzh em diversos dos seus textos anteriormente citados, mas encontra uma formulação mais detida em Stourzh $(1988,2007)$.
} 
Sua força prescritiva é, portanto, inseparável da ideia de que essas normas fazem parte da "constituição” jurídica de um Estado específico, ou seja, de um estado de coisas juridicamente constituído.

Não é indiferente, portanto, que, no debate político em torno das leis fundamentais de um Estado, o recurso à história para fundamentação de sua validade tenha desempenhado papel central. Em última análise, a força normativa das leges fundamentales tem como pressuposto a afirmação da existência empírica de uma norma intangível e vinculante. Não é esse o caso da nova ideia de "lei fundamental". Sua intangibilidade tem, comparativamente, um caráter muito mais abstrato e formal. A proteção, por exemplo, que é assegurada aos direitos individuais no interior de uma ordem constitucional não resulta apenas da afirmação do seu caráter objetivamente intangível, mas de uma operação jurídico-formal que os incorpora 400 no texto escrito de uma lei superior, capaz de tornar inválidas todas as normas contrárias aos seus preceitos. Nesse contexto, "a expressão lei fundamental ganha o sentido especificamente jurídico de lei suprema” (Beaud, 2009, p. 24). Essa supremacia, gostaria de reafirmar, é fruto de um procedimento jurídico e, portanto, o que confere superioridade a uma constituição é sua forma jurídi$c a$. Nesse sentido, a constituição moderna não se refere a certo estado de coisas, mesmo que esse seja, como no caso das leges fundamentales, um conjunto de leis que compõem situação jurídica de um Estado particular. Como assinala Dieter Grimm (2006, p. 49), ela já não designa "uma condição juridicamente configurada”, mas "a própria norma jurídica que a cria”. Ao se apresentar como a "lei fundamental", a constituição moderna estipula as condições jurídicas de validade da própria ordem pública, independentemente de sua realidade empírica ou de sua conformação histórica. 
Parece-me claro que, caso queiramos compreender as fontes históricas do que estou denominando de caráter abstrato das constituições modernas, devemos voltar nossa atenção para o papel desempenhado pelo universalismo dos princípios jusnaturalistas na elaboração dos seus conteúdos. Com efeito, a noção moderna de direitos subjetivos pressupõe um sujeito abstrato, o ser humano individual, que, no fim das contas, não existe em lugar algum. Gostaria, entretanto, de chamar a atenção para outro aspecto desse mesmo problema. No conceito moderno de constituição, a força constitutiva desses princípios jurídicos individualistas não resulta apenas do universalismo e da abstração de seus conteúdos, mas também de sua constitucionalização, ou seja, de sua inscrição no interior de uma lei concebida, em termos jurídico-formais, como superior. Sendo assim, a natureza abstrata do conceito moderno de constituição deriva, em grande medida, de um procedimento jurídico que, por assim dizer, entroniza (uso o termo de forma deliberada) determinados princípios como constitucionais. Esse procedimento, portanto, estabelece in abstracto - em outros termos, como um dever-ser que, sob muitos aspectos, prescinde do reconhecimento da evidência empírica de uma norma historicamente consolidada ou da validade objetiva de um preceito universal - as condições de legitimidade da própria ordem pública. Dito de forma simplificada, a constituição já não indica o que é a ordem pública e quais são as suas bases jurídicas; ela estipula os fundamentos jurídicos sobre as quais essa ordem deve se assentar.

A “juridicização da constituição" implicou, portanto, um movimento graças ao qual "progressivamente a noção de constituição afasta de si os seus componentes não jurídicos, se concentra no modo de ser jurídico do Estado e [...] vem a coincidir com a lei que regula a instituição e o exercício do poder estatal" (Grimm; Monhnhaupt, 2008, p. 111). 
Esse movimento, que desemboca numa ampla codificação da vida pública nos termos do direito, conduz, do ponto de vista da elaboração linguística da ideia de constituição, a uma consequência central: "o conceito não se define mais a partir de um objeto, mas se torna linguisticamente o próprio objeto, se autodefine" (Grimm; Monhnhaupt, 2008, p. 111). Os desdobramentos políticos dessa mudança são igualmente significativos. Enquanto a constituição pôde ser concebida como a designação de determinado estado de coisas - ou, dito em outros termos, enquanto a palavra implicou a remissão a um referente empírico -, não era possível imaginar uma ordem política à qual não correspondesse, mal ou bem, determinada constituição. A qualidade de uma constituição poderia ser objeto das lutas políticas, mas não sua existência.

A partir do momento em que a constituição passa a ser pensada em termos predominantemente prescritivos 402 - ou seja, a partir do momento em que a noção se torna autorreferente em termos normativos -, ela adquire uma força política adicional. Ela se desvincula, por assim dizer, da experiência histórica, de tal modo que a variedade das constituições "nacionais" e das leges fundamentales cede lugar, agora, à constituição e à lei fundamental. Desde então, só o ordenamento que cumpre determinados requisitos normativos, materiais e formais, pode ser considerado uma constituição (Grimm; Monhnhaupt, 2008, p. 111; Grimm, 2006, p. 49). Torna-se possível imaginar uma ordem política que seja ilegítima, simplesmente porque não possui uma constituição. Tal possibilidade fica evidente quando consideramos o artigo 16 da Declaração dos Direitos do Homem e do Cidadão de 1789: "toda sociedade na qual a garantia dos direitos não está assegurada nem a separação de poderes determinada não tem constituição".

Creio que já temos condições de passar à discussão sobre o conceito de politeia. 


\section{III}

O termo grego politeia é frequentemente traduzido nas línguas modernas por “constituição". Essa tradução não esgota, porém, os sentidos da palavra no grego antigo. Como observa Mogens Hansen, politeia

[...] significa, antes, a estrutura política total de uma polis: a 'alma' da polis, como podia ser metaforicamente denominada. E, uma vez que a polis é, primariamente, seus cidadãos, politeia também podia em contextos adequados significar 'direitos de cidadania', ou a atividade política de um cidadão individual, ou o conjunto do corpo dos cidadãos como uma entidade. [...] O conceito de politeia era, por natureza e origem, muito mais amplo do que aquilo que nós entendemos por 'constituição'. Todavia, na prática ele era usado de forma mais restrita para designar aquilo que, de um modo especial, ligava os cidadãos em uma sociedade: mais especificamente, as instituições políticas de um Estado,

e, num sentido especializado, a estrutura dos órgãos de governo do Estado (Hansen, 1999, p. 65).

Para uma compreensão adequada sobre o tipo de ordem constitucional que a noção de politeia implica, é preciso levar em conta como alguns desses sentidos, a despeito de sua diversidade e aparente dispersão, se articulam entre si. Em particular, é preciso ter em vista que a unidade do conceito resulta do fato de que, segundo Bordes (1999, p. 65), "politeia aparece como o resultado final da tomada de consciência progressiva da unidade polis-politai" ${ }^{20}$. Vejamos esse ponto com mais atenção, explorando brevemente a história do conceito na Grécia dos séculos VI e V a.C.

Segundo Christian Meier (1984, 1989, 1990), a noção de politeia surge no contexto de significativa transforma-

\footnotetext{
${ }^{20}$ A palavra politai é o plural de polites, cidadão.
} 
ção dos conceitos gregos, ocorrida no século V a.C. Do ponto de vista das noções constitucionais então disponíveis, essa mudança teria sido o resultado da passagem de um conjunto de conceitos referidos à ideia de nomos para outro conjunto estruturado em função do campo semântico de kratos. O século V a.C. teria presenciado, portanto, uma transição de conceitos nomísticos para conceitos cratísticos. As noções constitucionais do século VI a.C. - eunomia, disnomia e isonomia - remetiam a um ideal de justiça e de ordem que encontrava sua principal referência na ideia de nomos. A categoria central, nesse contexto, era a eunomia como a realização concreta desse nomos. A eunomia significava, portanto, a efetivação prática de uma ordem com conotações religiosas e de alcance totalizante. Ela designava a boa ordem do todo, em conformidade com uma ordem divina, e englobava a vida econômica e social, a organização da vida política e a realização de princípios éticos. Do ponto de vista conceitu404 al, essa reflexão só conhecia dois polos extremos, sem qualquer alternativa intermediária entre eles: a eunomia, como realização de um ideal de justiça que se presumia dotado de existência objetiva, e seu oposto, a disnomia. Dessa forma, esse ideal não era concebido "a partir de uma instância terrestre de poder” (Meier, 1984, p. 32). Mais precisamente:

[...] no século VI, a questão de saber quem reinava era apenas uma questão entre outras. O funcionamento dos tribunais, as relações de propriedade, as possibilidades econômicas, o caráter dos homens no poder, as relações entre as classes sociais, tudo isso era, no mínimo, igualmente importante para o estado da cidade. [...] Tudo parece indicar que o conceito de ordem política não existia ainda: a partir de que, com efeito, ele poderia ter se formado? A política e as relações entre os cidadãos como cidadãos não constituíam um fato independente, que se pudesse abstrair do conjunto dos acontecimentos sociais. Ou, então, apenas 
como o terreno de afrontamentos pelo poder entre os membros da nobreza. [...] No domínio da política não há, antes de tudo, outra coisa a não ser a alternativa entre a tirania e o poder da nobreza (Meier, 1984, p. 30-1).

Nesse contexto, a noção de isonomia, surgida na passagem do século VI para o V, possui um papel de transição. Por um lado, ela está associada à emergência da democracia e associa o problema da ordem constitucional a um valor eminentemente político, a igualdade; por outro, seu horizonte continua a ser o do princípio da eunomia, pela incorporação do tema da igualdade ao antigo ideal da justa ordem. Com isso, observa Christian Meier (1990, p. 162), o elemento propriamente político da igualdade entre os cidadãos não chega, com o conceito de isonomia, a se tornar o fator determinante na definição da ordem constitucional. Nesse sentido, é revelador que a ideia de isonomia tenha sido empregada contra o que se considerava o arbítrio da tirania e não contra o governo dos nobres.

A novidade dos conceitos que se formam a partir do século V - oligarquia, democracia, aristocracia etc. - reside no fato de que, com eles, o elemento político é projetado para frente da cena ${ }^{21}$. Torna-se possível pensar a ordem da cidade em termos das relações políticas que os cidadãos mantêm entre si. Daí a centralidade assumida por conceitos constitucionais "cratísticos", cujo eixo se encontra nas noções de arche e krathos, ou seja, expressando-me de forma um tanto frouxa, cujo eixo está no problema do poder. A importância que esses conceitos assumem na definição da ordem da cidade está diretamente associada ao surgimento da democracia. Quando o demos adquiriu voz ativa no plano político e, além

\footnotetext{
${ }^{21}$ Os conceitos de monarchia e tyrannis são anteriores e já podem ser atestados no século VI. No entanto, em suas primeiras aparições, esses conceitos "não caracterizam a ordem da cidade, mas apenas a repartição de poder no seio da nobreza" (Meier, 1984, p. 29).
} 
disso, se consolidaram canais institucionais regulares e permanentes para sua participação na vida pública, a "questão do poder [...] pôde se tornar um critério essencial - e, inclusive, rapidamente, o único critério - para reconhecer e diferenciar os tipos de ordem política" (Meier, 1984, p. 33). A ascensão da democracia representou um desafio ao domínio político, até então relativamente inconteste, da nobreza. Desse modo, foi possível formular as alternativas a respeito da ordem da polis tendo como ponto de referência o problema do governo. Dito em outros termos, essas alternativas acabaram por ser formuladas a partir da pergunta "quem deve governar: os nobres ou o povo?"

O surgimento dos conceitos cratísticos torna manifesta a possibilidade, que se abre a partir do século $\mathrm{V}$, de distinguir as poleis em função de diferentes formas de governo. O problema da ordem da polis ganha, assim, um novo significado. Ele se concentra na esfera do político e nas relações que os 406 membros da cidade mantêm entre si na condição de cidadãos. Esse novos conceitos constitucionais, quando comparados com as noções anteriores referidas a um nomos ideal, têm um alcance muito mais reduzido e implicam uma concepção de ordem muito mais restrita. Por outro lado, é justamente essa restrição que permite imaginar a ordem como algo que se encontra "à disposição dos cidadãos" (Meier, 1990, p. 163). No âmbito dos conceitos nomísticos, a justa ordem da vida coletiva se apresentava como um ideal a ser buscado pela ação dos homens, mas que, em última análise, era independente da sua deliberação. Quando o problema da ordem na cidade se concentra no plano do político e passa a girar em torno da pergunta sobre quem deve governar, o quadro de referência muda integralmente e um novo horizonte se abre para a ação humana. A natureza específica da ordem da vida coletiva depende, a partir de agora, das escolhas dos próprios cidadãos e, portanto, de instituições deliberadamente estabelecidas. 
Para Christian Meier (1984, 1990), a posição central que o plano do político assume na definição dos conceitos constitucionais do século V seria, na verdade, expressão de uma tendência mais ampla no sentido de uma politização, fruto da ascensão da democracia. O sentido dessa ideia se torna um pouco mais claro quando se considera o lugar da noção de igualdade no interior da democracia antiga. Nas sociedades modernas, a igualdade política encontra um suporte, por assim dizer, fora do âmbito da política, ou seja, na ideia de uma igualdade prévia de todos os seres humanos. Na antiguidade, a afirmação da igualdade política exigiu o estabelecimento de um espaço de relações específico, artificialmente constituído, no qual a equivalência entre os cidadãos pudesse ser efetiva. Dessa forma,

[...] abriu-se uma fratura entre a ordem social e a ordem política. Enquanto a sociedade, com todas as suas desigualdades, manteve-se basicamente inalterada, desenvolveu-se ao lado dela, separada dela e protegida por suas próprias instituições, a nova esfera política na qual todos eram iguais (Meier, 1990, p. 145).

Assim, a esfera da política teria ganho autonomia em relação aos demais âmbitos da existência coletiva, desembocando numa "mudança na estrutura das filiações sociais" (Meier, 1990, p. 165). Isso implica dizer que no plano das relações políticas, o fator que define a identidade dos membros de uma cidade é a sua condição política de cidadãos, e não as posições e os papéis que eles assumem em outros campos de sua vida. Segundo Christian Meier (1990, p. 144), a invenção da democracia num mundo que até então desconhecia a possibilidade de uma organização democrática da vida política não se restringiu a essa separação do político em face da vida social. É preciso levar em conta outro dado fundamental: "a cidade estava fundada 
nos seus cidadãos, não em um aparato estatal autônomo. Os cidadãos constituíam o Estado”.

Desse modo, a institucionalização da igualdade entre os cidadãos não se resolve com a montagem de uma estrutura institucional. Ela requer um engajamento na vida política que preserve, por intermédio da própria atividade dos cidadãos, a autonomia desse espaço de igualdade política. Trata-se, portanto, de institucionalizar uma "presença cívica"22 e de fortalecer os laços de uma identidade política baseada nas relações que os membros da cidade mantêm entre si em virtude de sua condição política de cidadãos. A tendência à politização seria uma consequência da prioridade que essa identidade política teria assumido na conformação das relações sociais no interior da democracia grega. A sustentação da democracia teria exigido que o conjunto das relações dos cidadãos como cidadãos - ou seja, sua identidade política - assumisse prioridade sobre 408 os demais vínculos da vida social. Sendo assim, a ideia de politização busca apreender

[...] a tendência central de uma mudança coletiva que fez da política a matéria mesma da vida cívica - na qual a comunidade encontrou sua identidade coletiva no voto e no processo decisório, no desempenho de funções públicas, na supervisão e na efetivação da ordem pública; na qual o político foi destacado como uma área autônoma, não de uma sociedade que opõe seus valores em relação ao Estado, mas de uma comunidade que foi literalmente identificada com o Estado, uma comunidade na qual a constituição (no sentido político do termo) foi colocada à disposição dos cidadãos. Esse tipo específico de politização ocorreu nas isonomias e nas democracias; ao mesmo tempo que

\footnotetext{
${ }^{22}$ Christian Meier desenvolve a noção de "presença cívica" no artigo "Cleisthenes and the institutionalizing of the civic presence in Athens" (Meier, 1990, pp. 53-81)
} 
remodelou a compreensão que os homens tinham de todo mundo político-social (Meier, 1990, p. 166-7).

Nesse contexto, a noção de politeia, observa Meier (1990, p. 172), representaria a "culminação", no plano dos conceitos, dessa tendência geral à politização. Por quê? Retomemos, por um instante, alguns dos significados de politeia que expus anteriormente: cidadania, comunidade dos cidadãos e ordem constitucional. $\mathrm{O}$ último desses sentidos apresenta-se por volta de 430 a.C. e, com o tempo, politeia toma o lugar de outras expressões que, previamente, também eram empregadas para designação da ordem institucional da cidade. Os significados de politeia, também já assinalei o ponto, embora distintos, estão estreitamente ligados uns aos outros. Em particular, a definição abstrata da natureza da ordem constitucional é inseparável da determinação da composição concreta da comunidade dos cidadãos. Isso porque, no quadro político e intelectual das poleis gregas do século $\mathrm{V}$, a ordem pública da cidade não é pensada apenas como uma organização institucional e uma estrutura de órgãos de governo independentes do conjunto dos cidadãos. A pergunta sobre a natureza dessa ordem está, no fim das contas, associada ao reconhecimento de uma identidade eminentemente política entre a polis e seus cidadãos, uma experiência que teria adquirido pleno sentido com a ascensão da democracia. Dessa forma, as noções de polis, polites e politeia estão estreitamente interligadas. Isso se torna claro quando colocamos lado a lado duas definições de politeia que Aristóteles oferece no livro III da Política:

A constituição é uma certa ordem instituída entre as pessoas que habitam a cidade. Mas, uma vez que a cidade faz parte dos compostos, assim como qualquer dos todos formados de muitas partes, é claro que é preciso, em primeiro lugar, realizar uma investigação sobre o cidadão. A cidade, com efeito, é um conjunto determinado de cidadãos. 
Uma constituição é, para uma cidade, uma organização de diversas magistraturas e, sobretudo, daquela que é soberana em todos os negócios. Em todos os lugares, com efeito, o que é soberano é o governo da cidade, mas a constituição é o governo. Quero dizer, por exemplo, que nas cidades democráticas o povo é soberano, ao passo que nas cidades aristocráticas é o pequeno número ${ }^{23}$.

Num sentido geral, a constituição, aqui, é uma determinada ordem da cidade. Mas, como nos diz Aristóteles, a cidade é, ela mesma, um composto de cidadãos e, desse modo, a constituição acaba por ser uma ordem dos próprios cidadãos. Ao mesmo tempo, essa ordem nos é apresentada como certa organização das funções públicas e das instituições políticas. Uma organização que determina quem, na cidade, ocupará uma posição de governo. Porém, numa comunidade de cidadãos como as poleis gregas dos séculos V e IV a.C., a 410 integração à vida coletiva se dá prioritariamente pelo acesso aos direitos políticos de cidadania, ou seja, o elemento definidor do pertencimento à cidade é a identidade dos indivíduos como cidadãos. Assim, participar do governo é, essencialmente, desfrutar da condição de cidadania. $\mathrm{O}$ acesso à politeia, entendida como os direitos de cidadania, significa poder participar da politeia, entendida como a estrutura das funções públicas e como o governo da cidade. Dessa forma, ao contrário do que à primeira vista pode parecer, a comunidade de cidadãos não é o pressuposto prévio da noção de politeia, a matéria, por assim dizer, que será organizada institucionalmente. A constituição, ao estabelecer uma estrutura

\footnotetext{
${ }^{23}$ Acompanho a tradução de Pierre Pellegrin (Aristóteles, 1993, pp. 205-6, 225). As passagens citadas pertencem a Pol. III, 1, 1274b, e III, 6, 1278b, respectivamente. Como observa Mogens Hansen (2006, p. 110), "a análise de Aristóteles de polis, polites, e politeia está em inteira sintonia com nossas outras fontes, atenienses e não atenienses, e o uso nas fontes de polis, polites, e politeia como três termos fundamentais conectados mostra que o autêntico núcleo do conceito de polis era o corpo dos cidadãos entendidos como participantes nas instituições políticas da cidade".
} 
de funções públicas e de órgãos de governo, não ordena uma comunidade de cidadãos preexistente. Ela define quem são os cidadãos com plenos diretos, ou seja, a própria composição do corpo dos cidadãos.

Há uma inevitável circularidade nesse modo de expor a questão: a constituição define a composição da comunidade dos cidadãos e a composição da comunidade dos cidadãos define a natureza da constituição. Essa circularidade não deriva apenas do fato de que a noção de politeia pode ter o duplo sentido de ordem constitucional e de comunidade dos cidadãos. Ela é, em grande medida, resultado da natureza politicamente concreta da polis grega. Nesta última, vale insistir, a comunidade dos cidadãos constitui a própria ordem política, ou seja, a ordem não se apresenta como um dado que lhes é exterior, como uma estrutura institucional dotada de uma fixidez e de uma continuidade que parecem prescindir dos seus portadores concretos. $\mathrm{O}$ tipo de ordem pública que decorre da noção de politeia não se esgota, portanto, em um arranjo institucional, mas, antes de tudo, refere-se à pergunta a respeito da composição e da extensão da comunidade dos cidadãos.

Em Atenas e em outros lugares se percebeu que a maneira mais efetiva de alterar uma constituição era ampliar ou restringir o número daqueles que desfrutavam de plenos direitos de cidadania ou vincular certos direitos políticos a uma qualificação em termos de propriedade ou algum outro tipo de exigência. Desse modo, foi possível assegurar que a questão decisiva era "quem são os cidadãos?” (Meier, 1990, p. 171) ${ }^{24}$.

\footnotetext{
${ }^{24} \mathrm{Na}$ coluna 1034 de Meier (1989) ainda podemos ler "na formação dessa palavra [politeia], se expressava o fato de que a cidade tornara-se idêntica à comunidade dos cidadãos e que a delimitação e a particularidade da comunidade dos cidadãos haviam-se tornado, com isso, a marca central da sua ordem".
} 
Essa pergunta, imagino que esteja claro, pressupõe a compreensão da ordem constitucional em termos especificamente políticos, pois envolve pensá-la em função do acesso aos direitos políticos que asseguram a participação na vida pública e no governo da cidade. Nesse sentido, as instituições representam, antes, um meio pelo qual a comunidade dos cidadãos se faz politicamente presente. Enfim, a ordem da polis e a comunidade dos cidadãos não podem ser concebidos separadamente porque os cidadãos não se encontram em face da polis, eles são a própria polis.

Aristóteles, mais uma vez, nos oferece uma ilustração muito esclarecedora desse ponto quando se pergunta, ainda no livro III da Política, se uma cidade permanece a mesma quando muda a sua constituição. A pergunta surge da tentativa de identificar o critério a partir do qual seria possível conceber a identidade e a continuidade de uma cidade no tempo. Segundo ele, não é o território, nem a composição 412 da população que determinam a natureza específica de uma polis. Sua resposta é conhecida:

[...] se a cidade é uma comunidade determinada, e se ela é uma comunidade de constituição entre os cidadãos, quando a constituição se torna especificamente outra, ou seja, diferente, pode-se afirmar que necessariamente a cidade não é mais a mesma, como de um coro, quando ele é cômico ou trágico, nós dizemos que não é o mesmo, ainda que seja frequentemente composto das mesmas pessoas (Aristóteles, 1993, p. 214) ${ }^{25}$.

A afirmação de Aristóteles se torna mais compreensível quando consideramos como nela os conceitos de polis e politeia (no duplo sentido de comunidade de cidadãos e de constituição) estão mutuamente remetidos. Se a consti-

\footnotetext{
${ }^{25}$ A passagem citada corresponde a Pol. III, 3, 1276b.
} 
tuição se confunde com a composição da comunidade de cidadãos com plenos direitos e se a polis é, ela mesma, uma comunidade de cidadãos, a natureza da cidade, em última análise, não se separa da composição concreta da comunidade dos cidadãos. Dessa forma, o conceito de politeia, ao conjugar os sentidos de ordem constitucional e comunidade dos cidadãos, dá expressão ao fato de que "a politeia não é simplesmente a constituição, que muda conforme as circunstâncias, de um Estado que se mantém o mesmo (como pessoa jurídica), mas precisamente a comunidade dos cidadãos" (Meier, 1989, col.1036) ${ }^{26}$.

É possível afirmar, então, que os sentidos de politeia, embora semanticamente diferenciáveis entre si, apontam, na verdade, para aspectos distintos de uma mesma questão. Falar de politeia como "comunidade de cidadãos" ou como "ordem constitucional" é, de certa forma, contemplar o mesmo problema a partir de perspectivas diversas, mas não divergentes: caso a ênfase esteja colocada na conformação institucional da cidade, prevalece o segundo sentido; caso esteja na composição da cidadania e, em particular, na composição do grupo dos cidadãos com plenos direitos, predomina o primeiro. Ainda que ao preço da repetição, não custa reiterar que essa diferença semântica se esmaece quando reconhecemos que os arranjos institucionais não possuem independência em relação aos cidadãos que exercem, eles próprios, as funções de governo na cidade.

\footnotetext{
${ }^{26}$ Essa observação de Christian Meier tem como referência precisamente a passagem de Aristóteles anteriormente citada. Veja-se também a seguinte observação: "Uma vez que na ordem política não se dependia mais tanto das instituições e das relações entre elas quanto da comunidade dos cidadãos ordenada, o conceito de politeia se sobrepôs às expressões mais antigas usadas para designar a instituição da cidade. Quando o traduzimos por 'constituição', apreendemos um sentido essencial; todavia, para a compreensão da palavra assim como das representações subjacentes, é importante ter em vista que, para os gregos, comunidade dos cidadãos [Bürgerschaft] e constituição significavam amplamente a mesma coisa. A comunidade dos cidadãos era antes a constituição do que tinha uma constituição" (Meier, 1989, col.1035).
} 
Na noção de politeia, portanto, a separação e a autonomia do plano do político em relação às demais esferas da vida social e, por conseguinte, a politização dos conceitos constitucionais se tornam patentes. Se a comunidade dos cidadãos se confunde com a própria ordem constitucional, a definição da natureza dessa ordem passa a depender da resposta que se dá a uma questão cujo centro de gravidade é político: "quem deve governar?", ou ainda, "quem são os cidadãos?” e, em particular, "quem são os cidadãos com plenos direitos?”. Nesse plano, o problema da ordem da cidade depende das escolhas e das ações humanas e pode ser objeto de uma reflexão autônoma. Sendo assim, penso poder afirmar que o conceito de politeia contém in nuce o problema que, segundo Leo Strauss, será a questão central da filosofia política clássica, isto é, o tema da melhor constituição, da ariste politeia (Strauss, 1986, pp. 128-35).

Podemos retornar, por fim, a Bodin e a sua distinção 414 entre o essencial e o acidental.

\section{IV}

Bodin formula sua análise sobre as diferentes formas de estat à luz da questão da soberania. Ao adotar essa perspectiva, o autor, coerentemente, rejeita a abordagem qualitativa das formas constitucionais. Para ele, apenas os elementos referentes à determinação da soberania são essenciais. Todo juízo sobre a qualidade do exercício do poder é acidental e se refere ao âmbito do governo, ou seja, a um aspecto da ordem de uma república que, do ponto de vista das premissas do seu argumento, tem uma posição secundária. Isso porque o problema da soberania, tal como Bodin o formula, não diz respeito ao modo como se exerce uma função pública, mas às condições de possibilidade desse exercício. Em Les six livres de la République, estas condições de possibilidade são, antes de tudo, jurídicas. Aqui, a soberania se apresenta como um lugar de comando supremo, estrutura- 
do juridicamente a partir de um conjunto de direitos exclusivos e permanentes. A definição de soberania proposta no capítulo 8 do livro I é, nesse sentido, exemplar: "soberania é potência absoluta e perpétua de uma república" (Bodin, 1583 , p. 122). De modo breve e preciso, ela busca identificar as características formais que determinam a condição de supremacia da posição de poder daquele que é soberano: a natureza última dos seus direitos de mando - ou seja, o fato de que estes direitos não derivam de outrem - e sua permanência no tempo - ou seja, sua duração não prefixada ou passível de suspensão repentina. Assim, o reconhecimento de quem é concretamente o soberano tem, como pressuposto anterior, a determinação formal das condições jurídicas que definem a posição de soberania.

Nesse contexto, a questão da qualidade deixa de ter um papel primordial no estabelecimento dos tipos de república, porque, para a definição da natureza do poder soberano, as condições formais que asseguram sua existência assumem prioridade conceitual sobre o modo efetivo do seu exercício. Trata-se de firmar os pressupostos da institucionalização de uma vontade como pública; uma vontade que será pública e suprema, ou melhor, pública porque, em termos jurídico-formais, suprema. Daí o modo particular como Bodin aborda o tema das "marcas da soberania" em sua análise sobre o poder soberano. Em lugar de definir a supremacia do príncipe ao modo tradicional - ou seja, pela enumeração de um catálogo de direitos que distinguiriam sua posição de comando - ele procura, primeiramente, estabelecer de maneira analítica os pressupostos jurídicos que conferem a essas marcas seu caráter soberano (Skinner, 2006, p. 559). Estas "marcas" constituem as prerrogativas que o soberano detém de forma absoluta e perpétua e que lhe conferem, no interior da ordem pública, uma posição de supremacia e, por isso, "não são comuns aos outros súditos, porque, se fossem comuns, não haveria príncipe sobe- 
rano" (Skinner, 2006, p. 212). Das prerrogativas de que dispõe um soberano, uma delas, na perspectiva do jurista, é a mais importante de todas e, em última análise, contém todas as outras: "a potência de dar a lei a todos em geral e a cada um em particular" (Skinner, 2006, p. 221), sem o consentimento de quem quer que seja.

Desse modo, Bodin não só descarta o problema da qualidade na discussão sobre as formas de república, mas também, em certo sentido, coloca uma pergunta prévia. Uma pergunta que se refere às condições institucionais sem as quais uma república sequer existiria. Esta pergunta prévia, quero crer, o conduz no sentido de uma integral redefinição dos termos da reflexão constitucional. E, ao fazê-lo, Bodin coloca algumas das bases intelectuais do conceito moderno de constituição. Com efeito, como vimos anteriormente, na noção de politeia o tema da ordem constitucional tem um dos seus eixos na pergunta "quem deve governar?" e, por exten416 são, “qual a melhor constituição para a cidade?”. Na resposta que se oferece a essa pergunta, a definição de uma estrutura institucional e a composição da comunidade cívica caminham juntas, pois na polis os cidadãos constituem a própria ordem política.

Repito esses pontos visando chamar a atenção para um aspecto que até agora não enfatizei e que, de certo modo, está implícito nessa discussão: no conceito de politeia, os temas da ação e do agente desempenham um papel fundamental. Se a noção de politeia está associada a uma consciência da unidade polis-politai, é porque a ordem da cidade se apresenta como uma atividade do conjunto da cidadania, antes de ser uma estrutura com que os cidadãos se defrontam. Bodin, por pensar as formas de república a partir do problema da soberania, formula outra pergunta: "quais são as condições graças às quais o governo e a própria cidade vêm a ser possíveis?" Gostaria de fazer algumas considerações em relação a esta pergunta. Em primeiro lugar, ela impli- 
ca deslocar o eixo da atenção para a estrutura jurídica que constitui o poder soberano e que, por assim dizer, fixa as premissas institucionais da ordem pública e da obrigação política. Tal estrutura é concebida como um dado anterior ao tema das formas de república e possui, no fim das contas, independência em relação a ela. Assim, a ênfase na articulação institucional da vida política adquire precedência e prioridade em relação ao ponto de vista da ação e do agente. Como resultado, a natureza politicamente concreta da ordem da politeia cede lugar a uma organização constitucional que tem como pressuposto a distinção entre Estado e sociedade. Numa ordem fundada nessas premissas, a constituição torna-se, ela mesma, uma forma de organização institucional ou, para ser mais preciso, uma forma de regulação normativa das instituições públicas. Como observa Dieter Grimm (2006, p. 51):

[...] em sua qualidade de regulação completa e unitária da organização e do exercício do poder, a constituição dependia da existência de um objeto que permitisse tal intervenção concentrada e normativa. [...] Só um poder político distinto e diferenciável da sociedade podia oferecer o ponto de partida para um trabalho de regulação expressamente dirigido à organização e ao exercício do poder e à sua concepção unitária; anteriormente à reunião dos direitos de soberania dispersos e a sua concentração no poder estatal pleno [...], não havia possibilidade de que existisse constituição moderna alguma. ${ }^{27}$

\footnotetext{
${ }^{27}$ Uma importante vertente atual da historiografia do direito e das instituições políticas tem insistido na tese de que essa organização unitária dos Estados modernos é muito mais tardia do que tendemos a supor. Ela teria sido, antes, resultado do processo de ordenação jurídica desses Estados, ocorrido a partir do final século XVIII, com o surgimento das constituições modernas. Não ignoro esse ponto. No entanto, para efeito de minha discussão, interessa-me destacar como a concepção moderna de constituição pressupunha, do ponto de vista conceitual, um objeto unitário, passível, nos termos da citação acima, de uma "regulação completa e unitária".
} 
Nesse sentido, a consolidação da ideia de Estado como pessoa jurídica pública - ou seja, como estrutura institucional juridicamente definida, dotada de unidade, permanência e continuidade para além dos seus portadores concretos é uma condição prévia da constituição moderna. Esta última é, em primeiro lugar, uma ordem do Estado. Ela constitui o exercício do poder estatal e, pode-se dizer, partilha de sua condição de exterioridade em face da vida social. Acredito, porém, ser possível levar adiante o argumento. Do ponto de vista de seus pressupostos conceituais, a ordem institucional do Estado moderno representa algo mais que uma condição prévia, ela define a linguagem a partir da qual se elabora o conceito de constituição surgido no final do século XVIII. Isso porque, ao buscar uma regulação do poder estatal, a constituição moderna parte da mesma linguagem que estruturou historicamente este poder, a linguagem do direito.

418 Com efeito, tanto o soberano da ordem estatal moderna, quanto o indivíduo titular de direitos fundamentais das constituições modernas são, acima de tudo, "seres legais"28. Eles se apresentam como sujeitos de determinadas capacidades jurídicas, ou seja, como portadores de títulos jurídicos que os qualificam, nas relações que mantêm com os demais membros da coletividade. Tais títulos os habilitam a fazer determinadas coisas e a exigir, com um grau variável de eficácia coativa, certos tipos de comportamento, em face de outros sujeitos igualmente definidos em termos jurídicos. A ordem que tem, nesses "seres legais", seus principais protagonistas envolve, por um lado, um esforço de regulação das relações que os agentes portadores de direitos estabe-

\footnotetext{
${ }^{28}$ Emprego, num contexto algo diferente, a expressão que J. G. A. Pocock (1995, p. 34) utiliza para designar, por contraste ao "ser político" que teria sido o cidadão na Grécia clássica, a concepção de cidadania derivada da tradição do direito romano.
} 
lecem entre si e, por outro, o reconhecimento institucional de suas capacidades jurídicas ${ }^{29}$.

Nesse sentido, a entronização jurídica de determinados princípios como parte da constituição do Estado foi precedida pela constituição jurídica do próprio "trono" estatal. Em outras palavras, a primazia do lugar de poder associado à soberania estatal e a supremacia da constituição moderna como lei fundamental resultam, igualmente, de sua forma jurídica. A superioridade da posição do soberano e a intangibilidade da constituição dependem, no fim das contas, de certas condições jurídico-formais. É verdade que, politicamente, essa supremacia apresenta, em cada um dos casos, desdobramentos opostos. A posição do soberano se caracteriza pelo fato de que ele é legibus solutus, isto é, detentor, em condições de exclusividade e permanência, de uma capacidade legislativa. A constituição, inversamente, implica um esforço de controle e regulação jurídica do exercício dos poderes públicos, por meio do estabelecimento de uma "lei fundamental". A ênfase nessa diferença, no entanto, não deve nos impedir de reconhecer o quanto a construção conceitual da constituição como "lei suprema" é tributária de uma estruturação jurídica da ordem pública, na qual a ideia de supremacia desempenha um papel decisivo. Esta ideia é o eixo de articulação e ponto de referência último a partir do qual o todo da ordem vem a ser pensado ${ }^{30}$.

\footnotetext{
${ }^{29}$ Nesse sentido, parece-me que Luc Foisneau tem razão ao afirmar que Bodin "[inaugura], a seu modo, a longa série das declarações de direitos que irão marcar a modernidade política. No mínimo, pode-se considerar que sua invenção - a declaração dos direitos de soberania - [...] prefigura na sua forma a declaração dos direitos do homem e do cidadão" (Foisneau, 2009, p. 57).

${ }^{30}$ Nessa discussão, deixei de lado, propositadamente, o fato fundamental de que a questão da soberania se repõe na história das constituições modernas por intermédio da ideia dos poder constituinte do povo. Interessa-me, aqui, destacar como a ideia de supremacia da constituição moderna tem suas premissas na construção conceitual do Estado moderno como uma entidade articulada em torno de uma noção jurídico-formal de supremacia.
} 
Nesse sentido, a tendência à "juridicização" que marca a história do moderno conceito de constituição é inseparável da conformação jurídico-institucional das relações políticas que, por sua vez, marca a formação do Estado moderno. Essa primazia dos vínculos jurídico-institucionais, que se observa na análise de Bodin sobre os tipos de república, resultará no fim das contas num esvaziamento do tema das formas constitucionais herdado da antiguidade clássica. Esvaziamento que será o resultado de uma redefinição, na linguagem do direito, do problema da ordem na cidade. Acredito que esse ponto pode se tornar um pouco mais claro a partir de uma consideração rápida e inevitavelmente superficial sobre a reflexão constitucional que Thomas Hobbes desenvolve no Leviatã.

Hobbes considera, no capítulo 19 do Leviatã, de modo semelhante a Bodin, que a distinção entre os tipos de república resulta exclusivamente das diferenças na com420 posição numérica do soberano. Sendo assim, só existem, para ele, três formas de governo: monarquia, aristocracia e democracia. As versões supostamente desviadas desses regimes "não são nomes de outras formas de governo, mas das mesmas formas quando detestadas" (Hobbes, 2005, p. 147). Algumas das consequências conceituais e políticas dessa perspectiva se evidenciam, mais adiante, quando Hobbes se confronta com a tradicional pergunta sobre qual desses três tipos de república seria preferível. Para efeito da minha discussão, a resposta que ele oferece para essa questão é menos importante do que os termos em que o problema é formulado:

[...] a diferença entre esses três tipos de república não consiste na diferença de poder, mas na diferença de conveniência ou aptidão para produzir a paz e segurança do povo, fim para o qual eles foram instituídos (Hobbes, 2005, p. 149). 
Duas observações a propósito dessa distinção entre diferença de poder e diferença de conveniência. Em primeiro lugar, se a diferença entre as formas de governo não diz respeito ao poder, é porque o tema do poder, assim como em Bodin, é anterior ao das formas de governo. Mais exatamente: as formas de república são secundárias em relação àquilo que torna possível a existência da própria república. À luz da questão do poder, portanto, os diversos tipos de repúblicas são equivalentes entre si. Dessa maneira, o problema fundamental em termos da ordem da cidade não está mais na decisão por uma das formas de governo, mas no estabelecimento de uma estrutura institucional que crie as condições do governo, fundando a autoridade pública e a obrigação de obediência numa racionalidade jurídico-formal ${ }^{31}$.

Em segundo lugar, ao transformar a distinção entre os tipos de república em uma questão de conveniência, Hobbes reduz a diferença entre as formas de governo a um ponto de vista instrumental. Monarquia, aristocracia ou democracia são despojadas de valor em si e vêm a ser avaliadas como meio para se alcançar a segurança e a paz do povo. Quando concede primazia ao tema do poder e reduz as diferenças entre as formas ao ponto de vista da conveniência, Hobbes realiza, por assim dizer, um movimento oposto àquele que teria caracterizado a formação do conceito de politeia na Grécia antiga. Ele despolitiza a discussão em torno das formas constitucionais, fazendo da opção por uma delas um problema de cálculo estratégico. Com isso, a pergunta sobre a melhor constituição se vê esvaziada de grande parte

\footnotetext{
${ }^{31}$ A distinção, proposta por Alessandro Biral (1991) e amplamente explorada por Giuseppe Duso (1999), entre os conceitos de poder e de governo - o primeiro como o objeto por excelência do pensamento político moderno a partir de Hobbes e o segundo como o eixo da política antiga -, embora corra o risco de um certo esquematismo, fornece alguns elementos para pensar essa depreciação do tema das formas constitucionais.
} 
do seu significado político, pois, a rigor, a questão fundamental a respeito da ordem pública já teria sido resolvida com o estabelecimento de uma estrutura de poder institucionalmente sólida. Em Hobbes, portanto, esse esvaziamento tem como pressuposto a primazia de uma racionalidade jurídico-institucional sobre a natureza substantiva das escolhas políticas.

Último ponto. Em Hobbes, essa primazia de uma racionalidade jurídico-institucional se desdobra na maneira como a ideia de lei fundamental será apresentada no capítulo 26 do Leviatã. Segundo ele,

[...] uma lei fundamental em toda república é aquela que, sendo eliminada, a república sucumbe e é completamente dissolvida, como um edifício cuja fundação é destruída. Portanto, uma lei fundamental é aquela pela qual o súditos são obrigados a sustentar qualquer poder que se deu ao soberano, seja ele um monarca ou uma assembleia soberana, sem o que a república não pode subsistir, tal é caso do poder de paz e guerra, de judicatura, de escolha de funcionários e de fazer o que considerar necessário para o bem público (Hobbes, 2005, p. 228).

A imagem da lei fundamental como uma fundação, um alicerce sobre o qual se ergue o edifício público não é nova. Hobbes, na verdade, está reproduzindo uma espécie de lugar-comum a respeito do tema. As leis fundamentais, normalmente, eram associadas às metáforas do organismo e da arquitetura ${ }^{32}$. Se a metáfora é convencional, o mesmo, penso, não se pode dizer da definição aqui proposta. A definição que Hobbes apresenta tem um viés claramente polêmico e está dirigida contra os defensores de uma inter-

\footnotetext{
${ }^{32}$ Sobre esse ponto, com exemplos correspondentes, ver Mohnhaupt (1988, pp. 125-8).
} 
pretação das leis fundamentais como limites ao exercício do poder político e, em particular, como limites resultantes de vínculos contratuais entre o governante e os governados (Thompson, 1986, p. 1114-5). Do ponto de vista conceitual, essa ênfase polêmica tem um importante desdobramento: no lugar da imagem das leis fundamentais como um conjunto de normas particulares, resultantes das singularidades da constituição de um determinado Estado, Hobbes propõe uma concepção abstrata. A lei fundamental se transforma em uma exigência normativa unitária dirigida à preservação da posição de poder do soberano. Sua definição, portanto, não pressupõe um estado de coisas constituído, ou seja, não remete às leis fundamentais de uma república específica. A partir da premissa de que a posição de poder do soberano constitui a condição de existência da própria república, Hobbes estipula uma prescrição de natureza geral. Sua caracterização da lei fundamental implica um movimento de abstração em face do dado histórico concreto e um esforço de elaborar o problema em função das condições possibilidade da própria ordem pública.

Assim, Hobbes formula uma noção de lei fundamental de caráter abstrato, unitário e geral, cuja força prescritiva deriva, em primeiro lugar, das exigências formais de uma racionalidade jurídico-institucional autorreferente ${ }^{33}$. Imagino que a essa altura o leitor já tenha se dado conta das possíveis aproximações entre essa noção de lei fundamental proposta no Leviatã e algumas das características do conceito moderno de constituição anteriormente discutidas. Não pretendo, com isso, afirmar que Hobbes antecipa a moderna compreensão jurídica da constituição como lei fundamental, o que seria, para dizer o mínimo, um equívoco em termos de análise histórica. Por outro lado, o que, a meu ver, autoriza

\footnotetext{
${ }^{33}$ Como observa Michel Foucault (1984, p. 284), "a finalidade da soberania é circular, isto é, remete ao próprio exercício da soberania. O bem é a obediência à lei, portanto o bem a que se propõe a soberania é que as pessoas obedeçam a ela".
} 
essas aproximações é, vale repetir, o reconhecimento de que, em ambos os casos, o problema da ordem da cidade é pensado em função de uma lógica jurídica que articula o todo a partir de uma posição de supremacia formalmente determinada. Nesse particular, a noção moderna de constituição não pode ser concebida fora do horizonte intelectual que está na base da "constituição" do poder do Estado moderno.

\section{Bernardo Ferreira}

é doutor em ciência política pelo Iuperj e professor de ciência política do Departamento de Ciências Sociais da Uerj.

\section{Referências bibliográficas}

ARISTOTELES. 1993. Les politiques. Paris: Flammarion.

BARROS, A. R. 1995. "Estado e governo em Jean Bodin". Revista Brasileira de Ciências Sociais, n.27, pp.129-37.

2006. "O direito de resistência na França renascentista". Kriterion, n.113, pp.99-114. 2001. A teoria da soberania de Jean Bodin. São Paulo: Unimarco.

BEAUD, O. 2003. "Constitution et constitutionnalisme”. In: RAYNAUD, P.; RIALS, S. (orgs.). Dictionnaire de Philosophie Politique. Paris: PUF. 2009. "L'histoire du concept de constitution en France: de la constitution politique à la constitution comme statut juridique de l'etat". Jus Politicum. n.3, pp.1-29.

BIRAL, A. 1991. "Per uma storia della sovranità". Filosofia Politica. vol.5, n.1, pp.5-50.

BÖCKENFÖRDE, E.-W. 1999. Stato, costituzione, democrazia. Milão: Giuffré,

BODIN, J.. 1583. Les six livres de la République. Paris: Jacques Du Puys. Disponível em books.google.com.br/books?id=XSE8AAAAcAAJ\&printsec=fro ntcover\&hl=pt-BR\&source=gbs_ge_summary_r\&cad=0\#v=onepage\&q\&f =false). Acesso em 04/03/2013.

BORDES, J. 1982. Politeia dans la pensée grecque jusqu'à Aristote. Paris: Belles Lettres.

DUSO, G. 1999. La logica del potere. Storia concettuale come filosofia politica. Bari: Laterza.

FIORAVANTI, M. 1999. Costituzione. Bolonha: Il Mulino.

FOISNEAU, L. 2009. Governo e soberania: o pensamento político moderno de Maquiavel a Rousseau. Porto Alegre: Linus. 
FOUCAULT, M. 1984. “A governamentalidade”. In: Microfísica do poder. Rio de Janeiro: Graal.

FRANKLIN, J. (org.). 1992. On sovereignty: four chapters from Six books of the commonwealth. Cambridge: CUP.

1969. Constitutionalism and resistance in the Sixteenth Century. New

York: Pegasus.

1973. Jean Bodin and the rise of absolutist theory. Cambridge: Cambridge University Press.

GOYARD-FABRE, S. 1989. Jean Bodin et le droit de la République. Paris: PUF, 1989.

GRIMM, D. 2006. Constitucionalismo y derechos fundamentales. Madrid: Trotta. ; MOHNHAUPT, H. 2008. Costituzione. Storia di un concetto dall'Antichità a oggi. Roma: Carocci.

HANSEN, M. 2006. Polis. An introduction to the ancient Greek city-state. Oxford: OUP. 1999. The Athenian democracy in the age of Demosthenes. Norman: The University of Oklahoma Press.

HOBBES, T. 2005. Leviathan. New York: Continuum.

MACILWAIN, C. H. 1991. Constitucionalismo antiguo y moderno. Madrid: Centro de Estudios Constitucionales.

MEIER, C. 1984. Introduction à l'anthropologie politique de l'antiquité classique. Paris: PUF.

1990. The Greek discovery of politics. Cambridge: HUP.

"Politeia". 1989. In: RITTER, J. et al. (orgs.). Historisches Wörterbuch der Philosophie. Basel: Schwabe, v.7.

MESNARD, P. 1951. L'essor de la philosophie politique au XVIe siécle. Paris: Vrin.

MOHNHAUPT, H. 1988. "Von den 'leges fundamentales' zur modernen Verfassung in Europa”. Ius Commune, v.25, pp.121-58

POCOCK, J. G. A. 1995. "The ideal of citizenship since classical times". In: BEINER, R. (org.). Theorizing citizenship. New York: State University of New York Press.

ROMILLY, J. 1959. "Le classement des constitutions d'Hérodote a Aristote”. Revue des Études Grecques, v.72, pp.339-43.

SEELAENDER, A. 2006. "Notas sobre a constituição do direito público na idade moderna: a doutrina das leis fundamentais”. Revista Sequência, n.53, pp.197-232.

SENELLART, M. 2006. As artes de governar. São Paulo: Editora 34.

SKINNER. Q. 2006. Fundações do pensamento político moderno. São Paulo: Cia. da Letras.

SPITZ, J-.F. 1998. Bodin et la souveraineté. Paris: PUF.

STOURZH, G. 1977. "American Revolution, modern constitutionalism and the protection of human rights”. In: MYERS, R.; THOMPSON, K. (orgs.). Truth 
and tragedy: a tribute to Hans Morgenthau. Washington: Transaction Publishers. 2007. From Vienna to Chicago and back: essays on intellectual history and political thought in Europe and America. Chicago: The University of Chicago Press.

1988. "Fundamental laws and individual rights in the 18th century constitution". In: BARLOW, J. et al. (orgs.). The American founding: essays on the formation of the Constitution. New York: Greenwood Press.

1979. "The Declaration of Rights, popular sovereignty and the supremacy of the Constitution: divergencies between the American and the French Revolutions". In: FOHLEN, C.; GODECHOT, J. (orgs.). La Révolution américaine et l'Europe. Paris: Centre National de la Recherche Scientifique.

STRAUSS, L. 1986. Droit naturel et histoire. Paris: Flammarion.

THOMPSON, M. 1986. "The History of Fundamental Law in Political Thought from the French Wars of Religion to the American Revolution”. The American Historical Review, vol. 91, n. 5, pp.1103-28.

TURCHETTI. M. 2001. Tyrannie et tyrannicide de l'Antiquité à nos jours. Paris: PUF. VALENSISE, M. 1987. "La constitution française". In: BAKER, K. (org.) The French Revolution and the creation of modern political culture (Vol. I: The political culture of the old regime), Oxford: Pergamon Press.

VATTEL, E. 1758. Le droit des gens ou Principes de la loi naturelle appliqués à la conduite et aux affaires des nations et des souverains. Tomo 1. Londres. (Disponível em: http://gallica.bnf.fr/ark:/12148/bpt6k865729. $\mathrm{r}=$ vattel+droit+des+ gens). 